\title{
Empathy as a Desideratum in Health Care - Normative Claim or Professional Competence?
}

\author{
Thiemo Breyer | ORCID: 0000-0003-0239-3090 \\ Professor for Phenomenology and Anthropology, Department of Philosophy, \\ University of Cologne, Cologne, Germany \\ tbreyer@uni-koeln.de
}

\author{
Anna Storms \\ Research Associate, Department of Philosophy, University of Cologne, \\ Cologne, Germany \\ anna.storms@caritasnet.de
}

\begin{abstract}
This article investigates the possible functions of empathic interpersonal engagement in the context of medicine and health care. While empathy can be understood in different ways on a theoretical level - as an embodied process of resonance and synchronization, as an affective process of emotional sharing, as a cognitive process of understanding the other, or as a narrative process of externalizing and communicating personal experiences - it is often called for on a normative level as a desideratum in the competence of medical professionals. We address this issue by introducing different models of the relationality between doctors and patients, in order to clarify which dimensions of empathy are relevant in which model and raise the question whether empathy is more than a nice-to-have virtue on the side of the professionals.
\end{abstract}

\section{Keywords}

empathy - resilience - professional ethos - health care 
In July 2019, the Süddeutsche Zeitung published an article entitled "Aspiring physicians must show empathy", 2 invoking a commonplace criticism of modern medicine and health care: doctors should be more empathetic and show more compassion for the existential distress and crises of their patients. A professional ethics has emerged here that connects to virtue theory and considers empathy as a service to the patients. But how can one determine the extent to which an empathic relationship is factually established and whether it has a health-promoting effect? It is true that certain aspects and dynamics of empathy can be isolated and made measurable in methodologically controlled settings, such as experimental psychological studies or questionnaires on subjective emotions in experiences of crisis. However, a proper description of empathic processes requires a more comprehensive phenomenological analysis in which the different dimensions of empathy (on the bodily, affective, and cognitive level) ${ }^{3}$ are related to each other. Especially those working in health care are confronted with emotionally challenging situations with patients and their relatives on a daily basis. The increasingly confusing organizational and political conditions of the health care system, such as the increasing demand for documentation, shortened periods of hospitalization, extreme time pressure and the requirement that more and more must be achieved with decreasing resources, makes the work stressful.

\section{$2 \quad$ Empathy as a Multidimensional Resilience Factor in Crises}

Many psychological studies show that social contacts are essential for general psychological and physical well-being and for maintaining and restoring health. ${ }^{4}$ In this context, social integration should be understood less as a sign of the high degree of resilience of appropriately integrated individuals, but rather as an intrinsic constituent of resilience: "Social support is a powerful resilience factor. Managing stress alone is much more difficult than managing stress in the presence of a caring person". ${ }^{5}$ In view of the strong tendencies towards individualization in modern societies and economic systems as well as the

1 Supported by the German Research Foundation (DFG) - Project Number 348851031.

2 Bartens, Medizin und Mitgefühl.

3 Cf. Breyer, Verkörperte Intersubjektivität und Empathie.

4 Cf. Kleftaras/Psarra, Meaning in life.

5 Hasler, Resilienz. Der Wir-Faktor, p. 5 (translations here and in the following ours). 
frequently made observation that there has been a drastic increase in perceived stress in industrial nations over the past decades, the social management of stress is particularly relevant. A common topos of cultural criticism states that the individualization and liberalization in modernity creates a subjectively felt compulsion to decide permanently for oneself, to choose one's identity, and to constantly reinvent oneself. ${ }^{6}$ The multitude of possibilities to do so does not appear as freedom, but as a burden. What is endangered by this is the interpersonal dimension of meaning or the "we-factor".

However, this also contains a genuine potential for resilience, insofar as this factor can be determined as mutual empathy between subjects with an awareness of co-experiencing something. In this sphere of intersubjectivity, the experience of togetherness does not serve as a means towards an overarching end, but is, as it were, an end in itself. The assumption that the sense of commonality is anthropologically grounded, can be corroborated, for instance, by studies on declarative pointing ${ }^{7}$ or on spontaneous helping behavior in infancy. ${ }^{8}$ This leads some theorists to postulate a direct connection between empathy and prosociality, discussed under the "empathy-altruism hypothesis". ${ }^{9}$ Although the danger that empathy can be misused for antisocial purposes has been increasingly pointed out recently, ${ }^{10}$ this does not make it superfluous to reflect on the resilience-promoting power of caring empathy.

On the bodily level, crises can endanger the basic structures of bodily wellbeing, for example through desynchronization and illness. In order to restore its ability to be responsive to the (social) environment, ${ }^{11}$ a resonance space and a personal counterpart are needed. Thus, in terms of the affective dimension of empathy, the other can function as someone who shares emotions with oneself, whereby the quality of experiencing the commonality in sharing the same feeling, albeit with different intensities and associations, can have a stabilizing and motivating effect. Such empathy does not only mean empathizing with and understanding the emotional situation of the other person. It also means that one is affectively involved in these events oneself. This joint experience can lead to an emotional discharge, which can contribute positively to affect regulation. Empirical studies provide evidence for a correlation between resilience and positive emotions in the sense that resilient personalities not only manage to counteract emotional distress with positive emotions from past

6 Cf. Han, Psychopolitik; Han, Müdigkeitsgesellschaft - Burnoutgesellschaft - Hoch-Zeit.

7 Cf. Liebal/Carpenter/Tomasello, Infants' use of shared experience.

8 Cf. Warneken/Tomasello, Helping and cooperation.

9 Cf. Dovidio, The empathy-altruism hypothesis.

10 Bloom, Against Empathy, esp. ch. 5.

11 Rinofner-Kreidl, Intuition und Resilienz, p. 77. 
experiences, but in particular to integrate intersubjectively shared emotions and memories. ${ }^{12}$ Experiencing or reliving episodes together that are charged with positive feelings increases concentration and creativity in dealing with crises. ${ }^{13}$ If building emotions can be strengthened through interpersonal resonance, as studies from synchronization research furthermore show, ${ }^{14}$ the interpersonal and affective levels of empathy are particularly important for the formation of resilience. In the study of concrete dyadic interactions, the connection between mimic-gestural articulations and interpersonal resilience has already been addressed, for example, through the positive emotional effect of being smiled at and laughing together. ${ }^{15}$

On the cognitive level, the resilience potential of empathy lies primarily in the additional mental perspectives on a situation of crisis offered by empathizing others. It is immediately apparent that in such shifts of perspectives lies the possibility of rethinking one's own position and thus the experienced crisis. In this process, expressions and behaviors are not perceived in isolation, but are embedded in larger trajectories that constitute stories.

On the narrative level, this means structuring the experience in such a way that it can be conveyed in meaningful units. Thus, when one speaks of narrative empathy, one is referring to a process of understanding that targets episodes and stories within which expressions and actions acquire their specific meaning. ${ }^{16}$ In this context, it is often already a relief for those experiencing a crisis if they are able to externalize their apperception of what is happening. Of course, there are also experiences that seem to defy narrativization, as in the case of traumata. ${ }^{17}$ However, in less drastic cases, the mediation of the experience through the construction of a narrative or through the invocation of collective lament and rescue narratives, such as in the Old and New Testament, along with addressing a counterpart who can witness empathically, has a potential for resiliently dealing with the crisis.

Resilience thus appears as a multidimensional phenomenon which involves an element of negotiation with oneself and with others on bodily, affective, cognitive, and narrative levels. The empathy of those who come into consideration as communication partners in such situations can contribute significantly to the outcome. This is especially true for those working in the medical and nursing sector, as they are confronted with a multitude of individual crises.

\footnotetext{
12 Ong/Edwards/Bergeman, Hope as a source of resilience, p. 1263.

13 Tugade/Fredrickson, Resilient individuals use positive emotions, p. 325.

14 Cf. Ramseyer/Tschacher, Nonverbal synchrony in psychotherapy.

15 Cf. Papa/Bonanno, Smiling in the face of adversity.

16 Keen, A theory of narrative empathy, p. 214.

17 Cf. Staniloiu/Markowitsch, Dissociation, memory and trauma narrative.
} 
What are the implications of these considerations with regard to professional relationships in health care?

\section{Different Understandings of Empathy in Professional Health-Related Interactions}

Despite the advances in medical technology and specialization, as well as the increasing digitalization of the health care system, the concrete interpersonal relationship between doctors and nurses on the one hand and patients on the other is still a core element of medical and nursing care. Not least in care ethics, the topos of care emphasizes the "assumption of responsibility in striving for the good for the other". ${ }^{18}$ The changes in health care and society, such as the individualization and diversification of life trajectories or the pluralization of value concepts, have also left their mark on the configuration of this relationship. While for a long time, a paternalistic understanding of care on the part of medical professionals dominated the relationship, this gradually changed, and patient autonomy was strengthened.

At present, "medical treatment [...] must be carried out with respect for human dignity and for the personality, the will and the rights of the patient, in particular the right to self-determination.". ${ }^{19}$ At the same time, however, a particular asymmetry characterizes the relationship between doctors and patients, since the latter are usually in a vulnerable, existential situation, i.e., a crisis, in which they experience themselves as helpless and turn to health care professionals with the assumption that those can help them on the basis of their expertise.$^{20}$ By strengthening patient autonomy, however, patients in turn attain the sovereignty of interpretation with regard to their biography and the intervening medical procedures. According to the physicians and ethicists Ezekiel and Linda Emanuel, this results in four ideal-typical models of the relationship between patients and professionals: the paternalistic model, the informative model, the interpretative model, and the deliberative model. Each of these models is, thereby, based on a different understanding of empathy or contextualization of the relationship with regard to expectations of an empathetic virtue on the side of the professionals to foster the healing process.

\footnotetext{
18 Haker, Feministische Bioethik, p. 174.

19 German Medical Association: (Model) Professional Code of Conduct for Physicians Practicing in Germany, § 7 .

20 Cf. Brody, The Healer's Power.
} 
In the paternalistic model, as the name suggests, the emphasis is on the competence of physicians, who act as guardians, deciding and acting on what they believe is appropriate for the patient. This model is, therefore, also called the "parent or priest model", ${ }^{21}$ according to which there are universally valid objective criteria for determining what is best for a person in a given situation. The patient's right to self-determination is reduced to consent to the decision of the person providing treatment. Such a model is used in emergency situations, in which a person is either not (or no longer) responsive, or in which there is an immediate necessity for life-saving action.

This is in contrast with the relational understanding of the informative model, which is also referred to as the "scientific, technical or consumer model". ${ }^{22}$ Here, the decision-making authority over the medical treatment process lies solely with the patient. Doctors are merely responsible for providing the relevant technical and professional information so that patients can make an autonomous decision. "The physician's value standards, his or her understanding of the patient's values, or his or her judgment of the importance of the patient's values must play no role". ${ }^{23}$ The model thus separates between medical-technical facts and their evaluation by the patient.

However, on the one hand, such an understanding of independence negates the fact that experiences of crisis can call the individual value system into question and shed a new light on goals, wishes, and ideas, so that insecurities and feelings of powerlessness may develop. On the other hand, the treating person's experiential knowledge regarding similar situations is excluded, which may ultimately depersonalize the relationship. The interpretative and deliberative models are situated between these two models: they are also more likely to be found in practice, since there are often no objective criteria on the basis of which doctors make a decision and since patients are rarely certain in advance about which values to apply in order to reach a decision on their own. Often times, it is simply gut feeling that drives patients in one or the other direction.

In the interpretative model, physicians function - in the sense of philosophical maieutics ( $\mu \alpha\llcorner\varepsilon \cup \tau\llcorner x \dot{\eta}=$ midwifery) - as guiding authority for gaining insight into the relevant value concepts together with the patient. In this way, it is possible to find out which, if any, conflicting values are dominant in the specific situation. The decision can thus be better placed in a meaningful connection with the patient's biography, ideas about life, and expectations concerning

21 Emanuel/Emanuel, Four models of the physician-patient-relation, p. 107.

22 Emanuel/Emanuel, Four models of the physician-patient-relation, p. 107.

23 Emanuel/Emanuel, Four models of the physician-patient-relation, p. 107. 
the future. In the discourse on patient autonomy, this model primarily aims at self-knowledge. With the help of the practitioner, patients ideally come to understand "who [they are] and how the different medical options affect [their] identity". 24

Similarly, the relationship between the treating person and the person being treated manifests itself in the fourth, the deliberative model, according to which physicians help patients to identify and select treatment options and goals. As in the informative model, physicians explain the medical situation to patients and, as in the interpretative model, they jointly explore the relevant values of patients. In this model, however, it is also the task of the practitioner to point out why certain available options appear more suitable than others from a professional point of view and why specific values may be more desirable. Nevertheless, this is not to be confused with the paternalistic model, since both parties involved jointly consider how to act in the specific situation. Physicians do not occupy the role of advisors - as is the case in the interpretive model - but rather that of a teacher or friend, with the goal of contributing to the patient's "moral development" 25 and thereby "enabl[ing] the patient not simply to follow unreflected preferences or values, but to consider alternative health goals and their value and consequences for treatment in conversation". ${ }^{26}$

While in recent decades, there has been a shift towards a greater emphasis on patient autonomy in medical decision-making, ${ }^{27}$ it is obvious that this is understood very differently in the models and that expectations are placed on physicians and their professional competence and virtues that do not always imply empathy. It seems clear that empathy does not play a role in all models in the same way. In an information-theoretical understanding of the relationship, physicians should not be immersed in empathic feelings towards the patient, but should present factual knowledge in an understandable and truthful manner. Empathy does not play an explicit role in the paternalistic model either. However, both the interpretative and the deliberative model presuppose a resonance between doctors and patients in order to find out together what is needed and desired in the given moment. This should be communicated on a narrative level.

\footnotetext{
24 Emanuel/Emanuel, Four models of the physician-patient-relation, p. 109.

25 Emanuel/Emanuel, Four models of the physician-patient-relation, p. 110.

26 Emanuel and Emanuel point out that in addition to these four models of interaction between physicians and patients, others are conceivable, such as an instrumental model, which they however reject. Cf. Emanuel/Emanuel, Four models of the physicianpatient-relation.

27 Cf. Deutscher Ethikrat, Patientenwohl als ethischer Maßstab.
} 
On the affective or emotional level, it implies an element of empathy on the part of the physicians. With regard to the cognitive dimension of empathy, it ultimately also means understanding the other person in order to support an evaluation of relevant values and needs. Thus, while different dimensions of empathy are touched upon in both the interpretive and deliberative models, only in the latter does this occur in a full sense of a multi-layered and multidirectional understanding of empathy. If we consider empathy not solely a one-sided process of putting oneself in the other's shoes, but as an interpersonal process, the alterity between the person treating and the person being treated is maintained in a special way in the deliberative model, since both parties can and should contribute their own point of view as discussion partners, without thereby giving up the aspect of attempting to understand the other. Rather, the views and values of physicians open up a reciprocity of the relationship.

On a cognitive level, this enables a shift in perspective, as other options for interpretation and action can be identified and integrated into the decisionmaking process. On a narrative level, too, the inclusion of stories about certain experiences can address and focus the generation of new contexts of meaning. However, due to the asymmetry of the relationship as well as the vulnerability of the person in crisis, a deliberative understanding of the interaction between physicians and patients bears the risk that, due to the specific and existential situation, empathy on the part of patients is difficult to achieve. Frequently, the fact of having to make a decision represents an emotional and cognitive overload for the person, so that he or she places the responsibility in the hands of the professionals, thereby implicitly relying on a paternalistic model. In addition, the deliberative model can also imply the dilemma that nurses, physicians, and other employees in the health care sector must always walk the tightrope between empathy with the fates of patients and at the same time maintaining a professional distance. ${ }^{28}$

In this context, an exaggerated expectation of the usually one-sided immersive understanding and sympathy, as in the case of friends and teachers propagated in the deliberative model, can bring about its own symptoms of strain and stress factors on the part of the person treating the patient, contributing to emotional burnout ${ }^{29}$ and hindering professional action. ${ }^{30}$ However, as some research suggests, emphasizing the emotional dimension in the relationship may also have health-promoting effects for the treating person, such as an

28 Cf. Wick, Overcoming Secondary Stress.

29 Cf. Modestin/Lerch/Böker, Burnout in der psychiatrischen Krankenpflege.

30 Cf. Batson, The Altruism Question; Hojat, Physician empathy in medical education. 
increase in self-efficacy. ${ }^{31}$ Should empathy therefore be understood as an integral part of the ethos of medical professionals, or only as a nice-to-have virtue?

\section{Multidimensional Empathy Is More Than a Virtue in Health Care}

Depending on the understanding of the professional relationship between physicians and patients, empathy can attain very different meanings. Within the framework of care ethics - an important resource also for the field of spiritual care - which focuses on the consideration of patients' needs, empathy can be understood as a duty or as a virtue in the sense of an attitude of care. Thus, empathy by itself may be unbiased when dealing with the descriptive characterization of the phenomenon (What can I know about the other? What does my empathy tell me?). However, it acquires an ethical quality when it is seen as morally desirable and becomes a question of recognition (How should I meet the other adequately and act to their benefit?). This is particularly evident in medical and nursing care contexts, where "target' and 'empathizer' are social roles that are linked to specific expectations and values". ${ }^{32}$

On a virtue-ethical account, which follows the Aristotelian-Thomistic tradition, physicians are characterized by the disposition to "habitually act for the good of the patient [...] and normally put this good above [their] own, so that [they] can be reliably expected to act accordingly". ${ }^{33}$ For physician and ethicist Edmund Pellegrino and philosopher David Thomasma, this attitude can be characterized by the eight virtues of fidelity to trust, compassion, phronesis (prudence), justice, fortitude, temperance, integrity, and self-effacement. ${ }^{34}$ Medical ethicists Tom Beauchamp and James Childress, on the other hand, emphasize only five virtues: compassion, discernment, trustworthiness, integrity, and conscientiousness. ${ }^{35}$

Both approaches define compassion in the sense of affective empathy as a central disposition of physicians and as an integral part of the profession. Caring as empathic sympathy is considered as an important dimension of care. Paying attention to the other and his or her well-being ${ }^{36}$ evokes a moral

\footnotetext{
$31 \quad$ Cf. Bolton, Who cares?

32 Breyer, Verkörperte Intersubjektivität, p. 241.

33 Pellegrino, Der tugendhafte Arzt, p. $5^{2}$.

34 Pellegrino/Thomasma, The Virtues in Medical Practice, ch. 2.

35 Beauchamp/Childress, Principles of Biomedical Ethics, ch. 2.

36 For example, the World Health Organization (wно) defines the concept of health as encompassing physical, mental and social well-being and not merely the absence of disease. Cf. World Health Organization, Constitution.
} 
sense of caring and emphasizes interpersonal interaction. ${ }^{37}$ However, such an understanding of empathy as compassion, which reduces it to the affective level, thereby also reduces the resilience potential of the other levels. ${ }^{38}$ Moreover, "an exaggerated expression of compassion [...] can be perceived as intrusive and harassing". 39

If one takes a closer look at medical practice and what is understood there by "clinical empathy", it becomes apparent that the affective dimension is also increasingly focused on in the understanding of empathy as a virtue, in a normative understanding. ${ }^{40}$ In addition, however, the cognitive dimension in the sense of perspective-taking is sometimes also discussed, which would lead to empathy as part of a professional ethos. In health-related contexts, empathy is thus not only linked with the process of identifying with the observable feelings of the other person, but its resilience-promoting potential is also perceived from a different perspective in the sense of reflective thinking about the causes and consequences of a crisis. ${ }^{41}$ Thus, different perspectivations of empathy can be found in care contexts: on the one hand, as a personality trait, which is also propagated in virtue-ethical approaches; on the other hand, as a process of communication or as a professional quality, ${ }^{42}$ as implied by the deliberative model of interaction between practitioners and patients. In nursing contexts, a moral dimension is emphasized in addition to an affective, cognitive, and performative one. ${ }^{43}$

In addition, empathy is often seen as part of emotional and social competence, especially in the context of training, ${ }^{44}$ which, along with knowledge, methodological, and personal competencies, is part of professional action and ethos and represents a skill to be learned. In the discussion about a hierarchization of action- and profession-related competencies, however, emotion-related skills are often considered less important than other professional domains and accordingly degraded to "auxiliary competencies". However, empathy, intersubjective understanding, and resonant connectedness can certainly contribute to obtaining more detailed personal information, for example, in an anamnesis interview. 45

\footnotetext{
37 Cf. Zimmermann-Acklin, Tugendethische Ansätze.

38 Cf. Dörner, Der gute Arzt.

39 Breyer, Verkörperte Intersubjektivität, p. 242.

40 Cf. Neumann, Analyzing the "nature" and "specific effectiveness" of clinical empathy.

41 Cf. Richter, Empathie. Gewinne und Verluste im Erwachsenenalter.

42 Cf. Yu/Kirk, Measurement of empathy in nursing research.

43 Cf. Morse, Exploring empathy.

44 Cf. Kaspar, Emotional competencies in geriatric nursing.

45 Cf. Neumann, Analyzing the "nature" and "specific effectiveness" of clinical empathy.
} 
On the other hand, admitting this, one runs the risk of functionalizing empathy merely as a door opener to access therapeutically relevant and care-related information, instead of viewing it as a genuine resilience- and health-promoting ability in itself. Particularly in view of the high degree of psychological and physical stresses that health care professions entail, the emphasis on empathy is viewed critically, as it may appear to be morally or politically motivated and does not seem to adequately address the everyday reality of those working in health care. Thus, nurses and doctors are confronted with a dilemma between expectations and practical implementation. ${ }^{46}$ In this regard, the nursing studies expert Karin Kersting developed the theory of "coolout", ${ }^{47}$ which addresses the experience of daily failure arising between (self-)demands and reality in nursing as well as the phenomenon of emotional dullness and coldness. This occurs because "what should apply according to the postulated norms does not apply systematically". ${ }^{48}$ Empathy is therefore not per se beneficial.

A similar conclusion was reached in a review of empirical studies on the development of empathy skills in medical professions, according to which these tended to decrease rather than increase in everyday practice. ${ }^{49}$ If the focus of the discussion of empathy in health care is usually on the patients, the empathizer himself or herself, in this case the medical or nursing staff, is rarely taken into account. With regard to the relevance of empathy for dealing with crises, however, it can be asked for whom empathy can have a resiliencepromoting function in health-related contexts.

The handling of emotions, crises and drastic events as well as the structural working conditions of doctors, nurses and other health care professionals are rarely discussed. However, a mindful handling of one's own and other people's feelings, experiences, and their processing represents a central dimension of care with regard to empathy as an interpersonal interaction. Various studies have pointed out that empathy-guided emotional work should be a central component of medical and nursing professionalism and empathy hence part of a professional ethos. ${ }^{50}$ Addressing empathy in the sense described above as a multidimensional interaction process is, however, a continuing challenge in the context of health care, for if it is appropriately trained, used and embodied, it can make an important contribution to dealing with crises on both sides

46 Cf. Curtis, Student nurse socialisation in compassionate practice.

47 Cf. Kersting, Theorie des Coolout.

48 Heinrich, Zum Stand einer Theorie der Ontogenese Bürgerlicher Kälte, p. 14.

49 Cf. Neumann, Empathy decline and its reasons.

50 Cf. Böhle/Glaser, Arbeit in der Interaktion - Interaktion als Arbeit; Büssing/Glaser, Fourstage process model; Giesenbauer/Glaser, Emotionsarbeit und Gefühlsarbeit in der Pflege. 
of the medical or nursing dyad - as part of the patient's as well as the professional's resilience.

\section{Biography}

Thiemo Breyer studied Philosophy, Anthropology, and Cognitive Science at the Universities of Freiburg and Cambridge. After obtaining a PhD in Freiburg and being a Postdoctoral Researcher at the Karl Jaspers Chair for Philosophy and Psychiatry at the University of Heidelberg, he became Junior Professor for Transformations of Knowledge at the University of Cologne in 2014. Since 2018, he is Heisenberg Professor for Phenomenology and Anthropology, and since 2021 also Director of the Husserl Archives at the University of Cologne. Within the DFG-funded Research Unit "Resilience in Religion and Spirituality", he is Principle Investigator in the project "Empathy and Resilience".

Anna Storms studied Catholic Theology, Philosophy / Applied Philosophy, British and American Studies and Pedagogy in Münster and finished her studies with the degrees Master of Education as well as Master of Arts (Major: Medical Ethics). It followed her dissertation in the field of Medical Ethics under supervision Prof. Dr. Christiane Woopen at the University of Cologne, before she joined the a.r.t.e.s. Graduate School for the Humanities Cologne as a research fellow within the project "Empathy and Resilience". She also works as a consultant for ethical and religious education in health care at the Diözesan-Caritasverband für das Erzbistum Köln e.V.

\section{Bibliography}

Baron-Cohen, Simon: Zero Degrees of Empathy. A New Theory of Human Cruelty and Kindness. New York, NY: Penguin Books 2012.

Bartens, Werner: Medizin und Mitgefühl. Angehende Ärzte müssen Empathie zeigen, in: Süddeutsche Zeitung, 2019, https://www.sueddeutsche.de/gesundheit/medizin studium-empathie-auswahlverfahren-1.4546284 (29.11.2019).

Batson, C. Daniel: The Altruism Question:Toward a Social-Psychological Answer. Hillsdale, NJ: L. Erlbaum Associates 1991.

Beauchamp, Tom L./Childress, James F.: Principles of Biomedical Ethics. New York, NY: Oxford University Press 2001.

Bechtoldt, Myriam N./Rohrmann, Sonja/de Pater, Irene E./Beersma, Bianca: The primacy of perceiving. Emotion recognition buffers negative effects of emotional labor, in:Journal of Applied Psychology 96 (5/2011), pp. 1087-1094. 
Bloom, Paul: Against Empathy: The Case for Rational Compassion. New York: Ecco 2017. Böhle, Fritz/Glaser, Jürgen (eds.): Arbeit in der Interaktion - Interaktion als Arbeit: Arbeitsorganisation und Interaktionsarbeit in der Dienstleistung. Wiesbaden: für Sozialwissenschaften 2006.

Bolton, Sharon C.: Who cares? Offering emotion work as a 'gift' in the nursing labour process, in: Journal of Advanced Nursing 32 (3/200o), pp. 580-586.

Breithaupt, Fritz: Die dunklen Seiten der Empathie. Frankfurt a.M.: Suhrkamp 2017.

Breyer, Thiemo: Das Phantom im Spiegel. Ein phänomenologischer Versuch über somatosensorische Plastizität und Leibgedächtnis, in: Internationale Zeitschrift für Philosophie und Psychosomatik 7 (2/2012), pp. 1-12.

Breyer, Thiemo: Verkörperte Intersubjektivität und Empathie. Frankfurt a.M.: Klostermann 2015.

Brody, Howard: The Healer's Power. New Haven, CT/London: Yale University Press 1992. Bundesärztekammer: (Muster-)Berufsordnung für die in Deutschland tätigen Ärztinnen und Ärzte in der Fassung der Beschlüsse des 121. Deutschen Ärztetages 2018 in Erfurt geändert durch Beschluss des Vorstandes der Bundesärztekammer am 14.12.2018. In: Deutsches Ärzteblatt, https://www.bundesaerztekammer.de/file admin/user_upload/downloads/pdf-Ordner/MBO/MBO-AE.pdf (date of last access: o6.12.2019).

Büssing, André/Glaser, Jürgen: Four-stage process model of the core factors of burnout. The role of work stressors and work-related resources, in: Work \& Stress 14 (4/200o), pp. 329-346.

Curtis, Katherine/Horton, Khim/Smith, Pam: Student nurse socialisation in compassionate practice. A grounded theory study, in: Nurse Education Today 32 (7/2012), pp. 790-795.

Deutscher Ethikrat: Patientenwohl als ethischer Maßstab für das Krankenhaus. Stellungnahme, Berlin 2016.

Dörner, Klaus: Der gute Arzt. Lehrbuch der ärztlichen Grundhaltung. Stuttgart: Schattauer 2001.

Dovidio, John F.: The empathy-altruism hypothesis. Paradigm and promise, in: Psychological Inquiry 2 (2/1991), pp. 126-128.

Emanuel, Ezekiel J./Emanuel, Linda L.: Four models of the physician-patient-relation, in: Journal of the American Medical Association 267 (16/1992), pp. 2221-2226.

Endreß, Martin/Rampp, Benjamin: Resilienz als Prozess transformativer Autogenese. Schritte zu einer soziologischen Theorie, in:BEHEMOTH-AJournalon Civilisation 7 (2/2014), pp. 73-102.

Ewers, Paula/Bradshaw, Tim/McGovern, John/Ewers, Bob: Does training in psychosocial interventions reduce burnout rates in forensic nurses?, in: Journal of Advanced Nursing 37 (5/2002), pp. 470-476. 
Fuchs, Thomas: Das Gehirn - ein Beziehungsorgan. Eine phänomenologischökologische Konzeption. Stuttgart: Kohlhammer 2010.

Fuchs, Thomas: The virtual other. Empathy in the age of virtuality, in: Journal of Consciousness Studies 21 (5/2014), pp. 152-173.

Gallagher, Shaun: Direct perception in the interactive context, in: Consciousness \& Cognition 17 (2/2008), pp. 535-543.

German Medical Association: (Model) Professional Code of Conduct for Physicians Practicing in Germany as amended by the resolutions of the 121st German Medical Congress 2018 in Erfurt modified by the resolution of the Executive Board of the German Medical Association on 14.12.2018, https://www.bundesaerztekammer.de/ fileadmin/user_upload/downloads/pdf-Ordner/MBO/MBO-AE.pdf (date of last access: 10.05.2021).

Giesenbauer, Björn/Glaser, Jürgen: Emotionsarbeit und Gefühlsarbeit in der Pflege Beeinflussung fremder und eigener Gefühle. In: Fritz Böhle/Jürgen Glaser (eds.): Arbeit in der Interaktion - Interaktion als Arbeit. Arbeitsorganisation und Interaktionsarbeit in der Dienstleistung. Wiesbaden: Springer 20o6, pp. 59-83.

Gopnik, Alison/Wellman, Henry M.: Why the child's theory of mind really is a theory, in: Mind \& Language 7 (1992), pp. 145-171.

Gopnik, Alison/Meltzoff, Andrew N.: Words, Thoughts, and Theories. Cambridge: MIT Press 1997 .

Haker, Hille: Feministische Bioethik, in: Marcus Düwell/Klaus Steigleder (eds.): Bioethik. Eine Einführung. Frankfurt a.M.: Suhrkamp 2003, pp. 168-183.

Han, Byung-Chul: Psychopolitik. Neoliberalismus und die neuen Machttechniken. Frankfurt a.M.: S. Fischer 2014.

Han, Byung-Chul: Müdigkeitsgesellschaft - Burnoutgesellschaft - Hoch-Zeit. Berlin: Matthes \& Seitz 2016.

Hasler, Gregor: Resilienz: Der Wir-Faktor. Gemeinsam Stress und Ängste überwinden. Stuttgart: Schattauer 2017 .

Hatfield, Elaine/Cacioppo, John T./Rapson, Richard L.: Emotional Contagion. Cambridge: Cambridge University Press 1994.

Heinrich, Martin: Zum Stand einer Theorie der Ontogenese Bürgerlicher Kälte. Oder: „Wie man kalt wird“ (Teil 3), in: Pädagogische Korrespondenz: Zeitschrift für kritische Zeitdiagnostik in Pädagogik und Gesellschaft 24 (1999), pp. 5-31.

Hoffman, Martin L.: Empathy and Moral Development. Implications for Caring and Justice. Cambridge: Cambridge University Press 2001.

Hojat, Mohammadreza/Gonnella, Joseph S./Mangione, Salvatore/Nasca, Thomas J./ Magee, Mike: Physician empathy in medical education and practice. Experience with the Jefferson scale of physician empathy, in: Seminars in Integrative Medicine 1 (1/2003), pp. 25-41. 
Kaspar, Roman/Döring, Ottmar/Wittman, Eveline/Hartig, Johannes/Weyland, Ulrike/ Neuerth, Annette/Möllers, Michaela/Rechenbach, Simone/Simon, Julia/Worofka, Iberé: Emotional competencies in geriatric nursing: empirical evidence from a computer based large scale assessment calibration study, in:Advances in Health Sciences Education Theory and Practice 21 (1/2016), pp. 105-119.

Katz, Julie R./Woods, Susan L./Cameron, Cheryl A./Milam, Steve: Essential qualifications for nursing students, in: Nursing Outlook $5^{2}$ (6/2004), pp. 277-288.

Keen, Suzanne: A theory of narrative empathy, in: Narrative 14 (3/2006), pp. 207-236.

Kersting, Karin: Theorie des Coolout und ihre Bedeutung für die Pflegeausbildung. Frankfurt a.M.: Mabuse 2016.

Kleftaras, George/Psarra, Evangelia: Meaning in life, psychologicalwell-being and depressive symptomatology. A comparative study, in: Psychology 3 (4/2012), pp. 337-345.

Krach, Sören/Cohrs, Jan C./de E. Loebell, Nicole C./Kircher, Tilo/Sommer, Jens/Jansen, Andreas/Paulus, Frieder M.: Your flaws are my pain. Linking empathy to vicarious embarrassment, in: PLoS ONE 6 (4/2011).

Landweer, Hilge: Therapeutik der Affekte. Leibliche Resonanz und Gemeinschaftsgefühle als Bewältigungsstrategien. In: Cornelia Richter (ed.): Ohnmacht und Angst aushalten. Kritik der Resilienz in Theologie und Philosophie (Religion und Gesundheit, Bd. 1). Stuttgart: Kohlhammer 2017, pp. 71-9o.

Liebal, Katja/Carpenter, Melinda/Tomasello, Michael: Infants' use of shared experience in declarative pointing, in: Infancy 15 (5/2010), pp. 545-556.

Maibom, Heidi L. (ed.): Empathy and Morality. Oxford: Oxford University Press 2014.

Manusco, James C./Sarbin, Theodore R.: The self-narrative in the enactment of roles. In: Theodore R. Sarbin/Karl E. Scheibe (eds.): Studies in Social Identity. New York: SAG E Publiations 1983, pp. 233-253.

Modestin, Jiri/Lerch, Marianne/Böker, Wolfgang: Burnout in der psychiatrischen Krankenpflege. Resultate einer empirischen Untersuchung. Berlin: Springer 2013.

Morse, Janice M./Anderson, Gwen/Bottorff, Joan L./Yonge, Oliver/O’Brien, Beverley/ Solberg, Shirley M./MacIlveen, Kathleen H.: Exploring empathy. A conceptual fit for nursing practice? in: Image 24 (4/1992), pp. 273-28o.

Neumann, Melanie/Bensing, Jozien M./Mercer, Stewart W./Ernstmann, Nicole/ Ommen, Oliver/Pfaff, Holger: Analyzing the "nature" and "specific effectiveness" of clinical empathy. A theoretical overview and contribution towards a theory-based research agenda, in: Patient Education and Counseling 74 (3/20o9), pp. 339-346.

Neumann, Melanie/Edelhäuser, Friedrich/Tauschel, Diethard/Fischer, Martin R./ Wirtz, Markus/Woopen, Christiane/Haramati, Aviad/Scheffer, Christian: Empathy decline and its reasons. A systematic review of studies with medical students and residents, in: Academic Medicine: Journal of the Association of American Medical Colleges 86 (8/2011), pp. 996-1009. 
Ong, Anthony D./Edwards, Lisa M./Bergeman, Cindy S.: Hope as a source of resilience in later adulthood, in: Personality and Individual Differences 41 (7/2006), pp. 1263-1273.

Papa, Anthony/Bonanno, George A.: Smiling in the face of adversity. The interpersonal and intrapersonal functions of smiling, in: Emotion 8 (1/2008), pp. 1-12.

Pellegrino, Edmund D.: Der tugendhafte Arzt und die Ethik in der Medizin, in: Hans-Martin Sass (ed.): Medizin und Ethik. Stuttgart: Reclam 1989, pp. 40-68.

Pellegrino, Edmund D./Thomasma, David C.: The Virtues in Medical Practice. New York, NY/Oxford: Oxford University Press 1993, pp. 63-161.

Ramseyer, Fabian/Tschacher, Wolfgang: Nonverbal synchrony in psychotherapy. Coordinated body movement reflects relationship quality and outcome, in:Journal of Consulting and Clinical Psychology 79 (3/2011), pp. 284-295.

Richter, David: Empathie: Gewinne und Verluste im Erwachsenenalter (Dissertation), Bremen 2009.

Rinofner-Kreidl, Sonja: Intuition und Resilienz, in: Thomas Fuchs/Thiemo Breyer/ Stefano Micali/Boris Wandruszka (eds.): Das leidende Subjekt. Phänomenologie als Wissenschaft der Psyche. Freiburg: Alber 2014, pp. 75-103.

Ritter, Joachim/Gründer, Karlfried/Gabriel, Gottfried (eds.): Historisches Wörterbuch der Philosophie. Vol. 4: Art. "Krise". Basel: Schreiber 2007, pp. 1235-1245.

Scheler, Max: Wesen und Formen der Sympathie. Bonn: Cohen 1923.

Staniloiu, Angelica/Markowitsch, Hans J.: Dissociation, memory and trauma narrative, in: Journal of Literary Theory 6 (1/2012), pp. 103-130.

Sturgeon, David: 'Have a nice day'. Consumerism, compassion and health care, in: British Journal of Nursing 19 (16/2010), pp. 1047-1051.

Tugade, Michele M./Fredrickson, Barbara L.: Resilient individuals use positive emotions to bounce back from negative emotional experiences, in: Journal of Personality and Social Psychology 86 (2/2004), pp. 320-333.

Waldenfels, Bernhard: Antwortregister, Frankfurt a.M.: Suhrkamp 1994.

Warneken, Felix/Tomasello, Michael: Helping and cooperation at 14 months of age, in: Infancy 11 (3/2007), pp. 271-294.

Weizsäcker, Viktor von: Der Gestaltkreis. Theorie der Einheit von Wahrnehmen und Bewegen. Stuttgart: Georg Thieme 1940.

Wick, Robert J.: Overcoming Secondary Stress in Medical and Nursing Practice: A Guide to Professional Resilience and Personal Well-Being. Oxford: Oxford University Press 2006.

Wiesing, Urban (ed.): Ethik in der Medizin. Ein Studienbuch. Stuttgart: Reclam 2012, pp. 107-110.

World Health Organization: Constitution, 1946, https:/www.admin.ch/opc/de/ classified-compilation/19460131/20140508000o/o.810.1.pdf (date of last access: 13.12.2019). 
Yu, Juping/Kirk, Maggie: Measurement of empathy in nursing research. Systematic review, in: Journal of Advanced Nursing 64 (5/2008), pp. 440-454.

Zahavi, Dan: Empathy and direct social perception. A phenomenological proposal, in: Review of Philosophy and Psychology 541 (2/2011).

Zahavi, Dan: Self and Other. Exploring Subjectivity, Empathy, and Shame. Oxford: Oxford University Press 2014.

Zimmermann-Acklin, Markus: Tugendethische Ansätze in der Bioethik. In: Marcus Düwell/Klaus Steigleder (eds.): Bioethik. Eine Einführung. Frankfurt a.M.: Suhrkamp 2003, pp. 200-210. 